\title{
Legal Base of Ownership of Land
}

\author{
Dr.Farooq Aziz, Syed Muhammad Fahim, Waqar Ud Din Usmani, \\ Muhammad Rizwan \\ Department of Business Administration Assistant Professor Federal Urdu University Karachi-Pakistan \\ Department of Management Sciences Assistant Professor DHA Suffa University Karachi-Pakistan \\ Department of Business Administration Assistant Professor Institute of Business Technology Karachi-Pakistan \\ Department of Business Administration Lecturer Dow University of Health Sciences Karachi-Pakistan
}

\begin{abstract}
Private ownership of land is normally recognized throughout the world and it is included in the term property i.e. the things on which man can claim the right of ownership. But in-fact it is a wrong assumption because land is a gift of God whereas rest of the items which are included in the term property are man-made items. Hence the combination of these two is not possible in any way. Moreover due to some other reasons private ownership of land is not possible. For example government who is the ultimate source of this right does not have any right to assign it to anyone else. Any social agreement does not give this right to government. Moreover land is a part of nature and no one has any right to capture it. This concept also violates the rights of ownership. Hence private ownership of land is not possible from any aspect.
\end{abstract}

Keywords: Land, Ownership, Property, Rights.

\section{Introduction}

One of the important aspect of the present capitalist economic system is the concept of four factors of production. These are land, Labour, Capital and entrepreneur. From economic point of view these are the inputs to the production process, whereas the finished goods are the output. Factors of production may be defined as resources required for generation of goods and services. A brief definition of these factors of production is as follows.
i. Land:
All natural resources.
ii. Labour:
All human resources.

iii. Capital:

All man - made resources

iv. Entrepreneur / Organization: He brings all factors of production together for production. (www.businessdictionary.com/factors of production.html) ${ }^{1}$

Since the right of ownership is recognized under capitalist economic system. Hence on that basis ownership of land is justified up-to unlimited extent, subject to the rules of state and duties which are associated with it under the law.

The basic objective of this paper is to take a critical review of the concept of private ownership of land, hence for this purpose it is divided in two parts. In the first part theoretical base of ownership of land is discussed. In the latter part through a critical analysis it is proved that, all arguments which are given in this regard are baseless and private ownership of land cannot be proved with them.

\section{Theoretical Base of Private ownership of land}

From the theoretical point of view land is considered as the part of property. As far as the term property is concerned, it may be in the form of objects, manufactured goods, intellectual rights, innovations, land / real estate etc. Like other items of property, it is assumed that, ownership of land can be obtained through by purchase, or gift, by establishment of trust and by operation of law. Since the term property means ownership of rights, it means that, owner of land automatically gets all those right which are associated with it. Traditionally these rights are:
i. Transfer or sale in any of the above ways.
ii. Use it as a security for loan (mortgage).
iii. To keep possession and use the item.
iv. To give possession of it to another.
v. To grant social contractual rights over it.
vi. To commit waste i.e. demolish a house.
vii. To keep the benefits of property.

\footnotetext{
${ }^{1}$ www.businessdictionary.com/factors of production.html
} 
viii. To exclude others e.g. non-owner etc.

(www.scribd.com/doc/7183524/The-Concept-of-Onwership) ${ }^{2}$

These rights are not absolute in their nature and may be change on the basis of nature of transactions. These rights are subject to some responsibilities e.g. payment of tax and should be in accordance with the laws of state.

This concept is recognized throughout the world and this is the reason that, sale and purchase of land is a common transaction in the whole world. It is important that, same arguments are given from religious point of view in favour of this concept. For example according to Muslim scholars Islam is not ready to draw any boundary line between the ownership of land and other things (Siddique 1968). Prominent Muslim thinkers generally accept this concept (Mududi 1994) and (Usmani 1998)

In-fact some arguments are also given against their point of view, which raise basic objections about the validity of their opinions. (Aziz, F. Khan, N.R. 2012). In the same line some basic objections may be raised about the validity of above mentioned concepts, because it can be proved that, prevailing concepts relating to the term property and ownership of land does not qualify any standard of reasoning. In the following second and last part of this paper these concepts are challenged on different grounds.

\section{Arguments Against the concept of private ownership of land.}

On the basis of following reasons this concept does not remain valid.

\section{i. Land Cannot Be a Part of Property}

Land can never be a part of property because land is a gift of God, whereas all the things included in this term are man-made items. So the land cannot be bracket with them. The nature, life, functions, background and all the characteristics of land are completely different from the man-made items. Actually these are two completely different things which in any way cannot be put together. Except land all the things included in the term property is the result of dint of human labour. Actually there is not any concept of human labour in making or building of land. Hence no logical reason can be given to put them in one set or any set of same items. Definitely it is illogical, hence this basic concept under which land is included in the term property proved baseless.

\section{ii. Absence of Authority of Government \& State}

In-fact the concept of ownership of land ultimately originates from the government of state. Ownership of a piece of land may be transferred to an individual through inheritance, by purchase or in the form of gift. In case of a group of persons or any legal identity (company or corporation) it may be done through purchase or gift or any order issued by the government. In any case this process will be done through the authority of the governments, who has the ultimate authority to do so. But the main question is does the government has the power or authority to do so?

Definitely neither government nor the state has any such authority. Its reason is quite simple and can be found in the age difference of these two institutions and earth. The life of these two institutions is hardly 5000 years, whereas the age of earth is in trillions of years. The simple question is how a person who is born after trillions of years from the birth of land can claim its ownership? Definitely it is not possible neither any logical reason can be given in this regard.

Moreover there is another big problem in this context. Both of these institutions are completely unstable, particularly the government. Unlimited governments are broken till today in different states of the world from the birth of this institution. Almost same situation is with state in such a situation how these institutions can claim any right on land? How can a completely unstable institution claim the right of ownership on that thing which is present from the $1^{\text {st }}$ day and will remain same till the Day of Judgment? Definitely it is not possible.

Another important point is that, all means by which ownership of property can be acquire, which are mentioned above, none of them are applicable on land. Government or state cannot acquire land by purchasing it from anyone else; neither can they get it through gift. Similarly it is not possible for them by establishment of trust and by any other means. When it is not possible for government as well as for state that, they cannot acquire land by all prevailing legitimate means then on what grounds they can claim any right on land? Definitely no justification can be given in This regard. In such a situation when these institutions personally do not have any right, then how they can transfer it to individuals, legal identities or group of people? Obviously they do not have any right to do so, it means that, the ultimate source of private ownership of land (government / state) do not have any legal ground to sale / purchase or transfer of land to anyone.

\footnotetext{
${ }^{2}$ www.scribd.com/doc/7183524/The-Concept-of-Onwership
} 


\section{iii. Social Agreement}

From sociological point of view government is formed through an assumed social agreement between people and government. But any so-called social agreement does not authorize any government to get the ownership of land. It is beyond the limit of this so-called agreement. Hence government cannot find any legal support from this aspect.

\section{iv. Land is Included in Nature}

Another important point is that, land is included in nature and how a man can claim the ownership of nature? No doubt it is not possible in any context.

\section{v. Violation of an Important Aspect of Ownership of Property.}

An important aspect of ownership of property is that, a person can be the owner of anything if the rights of other people are not violated. Concept of private ownership of land violates the rights of a big majority of the people particularly in developing countries and partially in advanced countries also. In case of developing countries big landlords exploit the rights of their farmers and exploit them with all available methods. They got huge benefits from the government in the form of support prices and subsidies. In many countries they got political power and make all economic policies in their favour. In many cases they do not pay any tax because agricultural income is exempted from tax. On this basis the concept of private ownership of land becomes a big problem for the whole economy and for the nation also. It means that concept of private ownership of land violates the legitimate rights of a majority of people, hence on this basis it is against of rules of ownership of property.

\section{vi. Unfair Advantages to Landlord}

Landlord takes all those benefits which are associated with the rights of ownership. Landlord possess the piece of land and use it for the security, taken loan against it, get advantages by transferring or selling it out and other benefits. All these benefits received by landlord do not have any legitimate base because as it proved in the above lines private ownership of land is not possible. Hence all of these advantages are completely unfair and illegal.

\section{vii. Increase Unequal Distribution of Wealth}

Another negative aspect of this concept is that, it increases the unequal distribution of wealth in any economy. For example in U.S.A $75 \%$ of privately held land is in the hands of $5 \%$ of the private land lords, (www.context.org./iclib/ico8/gilman) ( $^{3}$ since the share of agriculture sector in American economy is not so large hence its effect is not so significant. But in case of developing countries this concept is a basic reason of unequal distribution of wealth, which itself creates a lot of economic and social problems in the economy. Hence on this basis also this concept cannot be acceptable.

\section{viii. Land is For Whole Mankind Not Only For a Few Landlords}

The last argument is that, land is for the whole mankind, its benefits cannot be restricted to just few landlords. This concept restricts the benefits of land to just a few landlords against the whole mankind, which is open violation of human rights.

On the basis of above arguments it can be easily concluded that, concept of private ownership of land is completely baseless and do not have any legitimate base.

\section{Conclusion}

On the basis of above discussion it can be concluded that the general assumption under which land or real estate is included in the term property is wrong. Land or real estate cannot be the part of property because land is not a men-made item whereas all the items included in this term are men-made. There is not any correlation between these two things, hence cannot be included in the same set. Government or state which are the ultimate source of this right, personally do not have any right to do so, hence any landlord do not have any legitimate right to sale / purchase or possess or transfer or take any advantage from the land. Any social agreement cannot give right of ownership of land to government. This concept is also baseless because it gives many undue advantages to landlord on the basis of that thing, on which landlord cannot prove his ownership. Another problem is associated with this concept is that it violates the rights of many people and gives the undue advantages to landlord. Land definitely is a part of nature and the claim to own the nature is simply impossible. This concept is further impossible because land is for whole mankind not only for a limited class of landlords. Hence on the basis of above arguments private ownership of land is not possible.

\footnotetext{
${ }^{3}$ www.context.org./iclib/ico8/gilman
} 


\section{References}

[1]. Aziz, Farooq, Khan, N.R., (2012) 'Refutation of Private ownership of land',

[2]. Journal of Islamic Economics, Banking \& Finance, 8(2), 81-90

[3]. Aziz, Farooq, Abbas, Hussain, Aqil, M. Samad, Abdul, (2011) Double Standard of Remuneration of Different Factors of Production in a Capitalist Economy',

[4]. European Journal of Social Sciences, (23) 2, 318 - 322

[5]. Mududi, Abul A'la (1994) 'Mushiat-e-Islam (Urdu) $15^{\text {th }}$ edition', Lahore, pp. $190-191$.

[6]. Siddiqui, M.N., (1968) 'Islam Ka Nizria-e-Milleiat (Urdu)', Lahore, pp. 89 - 91.

[7]. Usmani, M.T. (1998) 'Milkiat-e-Zamin Aur Uski Tahdeed, (Urdu)', Karachi, p. 10

\section{FOOTNOTES}

1. Website: (www.businessdictionary.com/factors of production.html)

2. Website: (www.scribd.com/doc/7183524/The-Concept-of-Onwership)

3. Website: (www.context.org./iclib/ico8/gilman) 